\title{
Pen, Ink, Keys, and Cards: Some Reflections on Library Technology
}

\section{Michael Stuart Freeman}

\begin{abstract}
Librarians have been adapting to new technology since the library profession's earliest days. Some ideas succeeded even in the wake of sustained and compelling opposition. This essay focuses on two major nineteenth-century innovations and looks at library methods that predated their introduction. The author finds that established practices persist in libraries, with new and older technologies often coexisting for many years.
\end{abstract}

ne of the most interesting artifacts related to library technology comes not from the world of computers, or from publishing, or from our own ranks. It comes from Hollywood in the form of the delightful 1958 film Desk Set. The film stars Spencer Tracy as what people today would call a systems analyst and Katharine Hepburn as a librarian for a broadcasting network with headquarters in what looks like Rockefeller Center. $\mathrm{He}$ is employed to introduce a monumental electronic brain to increase productivity, and she heads a special library whose staff must respond to reference questions on every imaginable subject. Of course, the machine Tracy introduces blunders, pink slipping the entire corporation by mistake, but it also answers some very difficult questions in a flash. The librarians, in the end, come to realize that the machine cannot replace them, but is actually a handy searching tool, and Spencer Tracy, who turns out to be a sensible guy, learns the value of intelligent and experienced humans. Eventually, there is love between the principals, with the best line in the film going to Hepburn, who, upon see- ing the computer go down, exclaims, "Peace. It's wonderful."

This film has unintended meaning and serves as an interesting cultural artifact. Desk Set is engaging and funny because the dramatized conflict-between the machine and the librarian, and between differing ideas of quality and efficiency-is precisely that found in libraries today as automation changes traditional library work. When looking at the ways librarians perceived technology in the precomputer age, there are, indeed, fossils that have to be examined (and sometimes exhumed).

When Richard Garnett, Keeper of Printed Books at the British Museum, proposed in 1893 the installation of the printing telegraph in the museum's reading room (he originally had suggested the idea seventeen years earlier), he was attempting - in this case through the use of a mechanical aid-to reduce the library's dependence on human labor and, at the same time, more efficiently retrieve books from the museum's stacks. In rejecting the telephone for internal communication, Garnett was also demonstrating, as would his modern-day professional counterparts, the librarian's preference for writ-

Michael Stuart Freeman is Librarian of the College, Magill Library, Haverford College, Haverford, Pennsylvania 19041. 
ten output. In not even suggesting the potential of the printing telegraph for interlibrary communication, he was revealing a priority for early librarians: to serve the home institution and its clients first and foremost.

The printing telegraph was actually the second mechanized innovation Garnett cited as necessary technology for the British Museum; the first, of which he was very proud, had been installed only a few years before. What was it? Electric lighting. ${ }^{1}$

It is interesting to observe what librarians thought technological innovations would do and how they expected these inventions to change their work. We may chuckle at John Cotton Dana's proposal in 1907 to use vending machines, just coming into popular use for chewing gum and novelties, to display and circulate books, but the concept behind the machine-that of the self-service library-was and is a good idea. In his suggestion that users insert their library card (or more precisely an encoded metal strip "not larger than a Yale key") so borrower data could be recorded, we see a distinctly modern application of technology to solve a library problem. ${ }^{2}$

The two ideas of Garnett and Dana noted above never got very far, nor did the fireproof book, the Rudolph Indexer, and at least three other coin-operated book-dispensing devices. ${ }^{3}$ Other ideas, such as the electric pen, looked promising, at least at first, judging from comments in the library press in 1877 and 1879 . The pen's story proves that inventions must not only serve a general need, they must adapt to the specific requirements of libraries and conform with other existing technologies. Invented by Thomas Alva Edison and patented in 1876 , the electric pen was a writing instrument that used electromagnets and a small storage battery. The actual pen, connected by wire to the power source, resembled a sewing needle; it produced small punctures in the form of letters and numbers, and when an inked roller was passed over the resulting stencil plate, legible copies could be made. The number of libraries that actually purchased the electric pen is unknown, but libraries quickly perceived its usefulness for catalog card reproduction and for lists of new acquisitions. Capable of producing as many as 2,000 copies with each stencil-many times the number possible with simple manifold slate systems also new to the market-the electric pen was highly touted by library leaders, including Melvil Dewey. But there were problems. The weight and bulk of the writing instrument meant that letter formation was slow; the pen had to be held perpendicular to the paper, so penmanship quality was difficult to maintain. More importantly, libraries had little need in their own internal work for a process that could produce so many copies of handwritten media. And although it was cheaper than printing, the quality of copies from the electric pen was inferior. Finally, for card reproduction and general purpose copying within libraries, the electric pen proved to be inconvenient and not without ongoing cost because the storage battery needed continuous tending. Soon the business world and eventually libraries would need typewriter-based duplicating systems, and the electric pen, after a short run, faded into oblivion. ${ }^{4}$

\section{Other ideas, such as the electric pen, looked promising - at least at first.}

Some ideas did take hold and succeed, sometimes in the wake of sustained opposition many years after the original proposals surfaced and with results not necessarily foreseen or intended by early prognosticators. This essay will look at two innovations from the nineteenth century, the card catalog and the typewriter-innovations that are so commonplace today, it is difficult to understand how they could have been considered radical or even controversial by earlier librarians. But a well-rounded picture is impossible if we do not also look at relevant antecedents. The card catalog and the typewriter are so much part of our experience that there is little apprecia- 
tion of what came before them; but it will serve librarians well to remember that before the card catalogs, there were excellent book catalogs, and before typewriters, skilled librarians produced cards and lists by hand, cultivating a highly refined and extraordinarily clear style of writing. The sets of practices that were discarded by growing libraries seem now to be part of the prehistory of librarianship, but these old systems were defended by contemporaries for decades and for more than just sentimental reasons.

The examination of earlier technologies in this essay has particular relevance today because libraries are quickly changing their methods and stepping up their pace of change. ${ }^{5}$ Are there lessons for us in the past as we approach a new millennium? We shall see that many of the issues that moved librarians to write fervently about new inventions and new procedures can inform the current debate about the electronic revolution.

\section{CARD CATALOG}

The printed book catalog was clearly the preferred method of documenting a collection until the last quarter of the nineteenth century although, in most libraries, accession books, handwritten lists, and the librarian's memory served as primary access tools. ${ }^{6}$ Printed catalogs ranged from simple finding lists (Lake Forest, 1893), to topic lists with authors and short titles (Wooster, 1892), to formal volumes with precise bibliographical data and detailed indexes (Bowdoin, 1863). Even some handwritten book catalogs were fairly ambitious. Tools produced at St. Lawrence University and Davidson College were done with pen and ink, but had author and title lists (and in Davidson's case a subject sequence) as well. ${ }^{7}$ The library literature after 1880 is filled with debates about the relative efficiency of printed book versus card catalogs but, for most libraries, the choice was to print as a book what was already in handwritten form or to produce cards, either by hand or through use of a typewriter, to represent holdings.
The book catalog had many advantages. It was a form familiar to librarians and library users and, besides its informational value, the book catalog put the library before the world just as exhibition catalogs or special collection guides do today. Haverford College's elegant 1836 book catalog of its 1,500-volume collection served as an advertisement for the new school and said much about institutional purpose and Quaker aims for higher education. ${ }^{8}$ Printed book catalogs projected a positive cultural image and, in some cases, were printed with the same monumentality characterizing the ornate library buildings then in evidence and coveted in America. But costs could be high; the book catalog of Bowdoin College, one of the best ever produced in the nineteenth century, went well over budget, forcing the librarian to make up the deficit from his own pocket. ${ }^{9}$

The book catalog also had practical advantages. Unlike the card catalog that had to be consulted in one place, the book catalog was a portable index that could be carried to a comfortable and well-lighted area and perused at leisure. Multiple printings of book catalogs provided better security than card files, which could be stolen, defaced, or misfiled. Card catalogs also required a large space commitment for libraries, and many scholars considered them cumbersome. "To use one, when it becomes large, involves vexation of spirit, with great loss of time," said Justin Winsor in the pages of The Nation in $1891 .^{10}$ The Examining Committee of the Boston Public Library was concerned in 1898 that card catalogs were less efficient for users because "100 titles can be run down a printed page with vastly greater rapidity than the same number of cards can be turned over."11 And then there was the problem later known as queueing. Again, Winsor explained:

The inevitable makeshift is a compression which gives six or eight drawers, up and down, and this means that a user, standing at the case, prevents other access to many thousand cards for as long a time as the 
weariness of consultation holds him at the drawers. This is a most serious drawback in a library of much use. ${ }^{12}$

Display and queueing worked at cross purposes. The Rudolph Continuous Indexer, in which cards on sheets of pressboard were rotated on drums, held 12,000 cards and displayed 175 cards at a time, but could be consulted by only one user at a time. To achieve the visibility of the book catalog, a library had to duplicate the card catalog and purchase additional Indexers. ${ }^{13}$ Some libraries tried a card-volume system in which several cards were mounted on pages that were mechanically bound together. The volumes, which looked like ordinary books, were shelved alphabetically and could be easily consulted by users. By having each volume hold no more than 250 cards, the system seemed to arbitrate the problem of display and queueing. Proponents contended that "leaves of a volume pass more rapidly under the eye than slips placed-often tightly packed-in drawers." ${ }^{14}$ The problem was keeping the volumes in order as their numbers grew and, of course, keeping them current with new cards.

Twentieth-century librarians also commented about card catalogs. John Cotton Dana in 1902 thought they might become "bibliothecal Frankensteins" as libraries continued to grow (he foresaw with horror libraries of a million volumes and catalogs of five million cards). ${ }^{15}$ Fremont Rider, in 1938, predicted that, as with biological organisms, the seemingly entrenched card catalog would one day wither away:

Differentiation, development, gigantism, disappearance-these seem to constitute the inevitable sequentiae of all progress. That the card catalog has today reached the gigantic stage, few librarians would probably deny; that it has also reached the "gigantistic" stage is probable. ${ }^{16}$

For all its defects, the card catalog had one advantage: the ease with which it could be maintained in an alphabetical arrangement, permitting what Rider called "immediate and indefinite inter- calation.."17 Card catalogs could be kept up to date and, by the latter part of the nineteenth century, that was the most important element in any successful catalog. Publishing output had increased tremendously and, with more books available, library collections began to grow very fast. No book catalog could hope to keep up. Also, the public demanded subject, title, and author access to the collection-something the book catalog could accommodate only with further delays. Hopes of using the more flexible Linotype as opposed to the early foundry type and preserving slugs in alphabetical order for future printings came to nothing because of the expense required to preserve such a large amount of metal. Linotype, applied successfully for decades to periodical indexes, never proved practical for individual libraries. It was offset printing and later the computer that revived the book catalog in libraries.

\section{Printed book catalogs projected a positive cultural image and, in some cases, were printed with the same monumentality characterizing the ornate library buildings then in evi- dence and coveted in America.}

The library world, however, sacrificed more than just ease and grace when the book catalog failed in American libraries. A card catalog is "a bibliography in an edition of one copy" and, for most of its history, there was "no way of multiplying copies cheaply and easily, as we may multiply copies of the line of a printed book."18 Sadly, librarians have searched an entire century for an illusive goal, the perfect duplicating machine.

The card catalog was one of those library inventions that greatly helped individual libraries, but it did so at the expense of library cooperation. While it is true that many bibliographies were published and that they benefited from card catalogs that listed current holdings, communication between libraries would have had a different history if 
catalogs had been transportable. Distance was always a deterrent to the scholar needing resources, and card-based catalogs meant that libraries in the same city were often unaware of each other's holdings. Card catalogs also proved so labor intensive that libraries could find time to prepare printed finding aids or subject lists for only small parts of their collections. The card catalog is the ultimate local source, and perhaps librarians' preoccupation with it for a century or more has contributed to the single library mindset so often criticized and even ridiculed by the public at large.

\section{TYPEWRITERS}

Early typewriters (before 1867) failed because they could not type as fast as a person could write, but by the middle of the $1870 \mathrm{~s}$, with the introduction of the so-called "advanced" design typewriter, which offered individual typebars, each carrying a single type and each operated by a single finger, the machine came into its own. ${ }^{19}$ The typewriter was introduced in this country at the same time libraries adopted card catalogs, but the two innovations-which to twentieth-century librarians seem to go hand in hand-usually involved separate decisions for libraries. Libraries began acquiring typewriters in the 1880 s, and from the 1890 s through the first decade of the twentieth century, many librarians commented in the library press about various features and the utility of individual brands. But many libraries did not purchase their first machine until much later-as late as the 1920 s in some cases..$^{20}$ In the meantime, practitioners skilled with pen and ink serviced card catalogs. The reasons so many libraries continued to use handwritten catalogs are worth examining.

The cost of equipment aside, librarians had reservations about using typewriters, and so did the general public. In the $1880 \mathrm{~s}$, it was considered insulting to use typewriters for private correspondence. It was thought, for instance, that a typewritten letter from a man was not really personal because it would generally have required a professional operator's help to produce. ${ }^{21}$
Some librarians also considered the typewriter to be ill-suited to library work. Typewritten cards "lacked character" and the typewriter produced letters with "disconnected, jerky style," lacking the "ease and expressiveness" that the same author's handwriting might have possessed. ${ }^{22}$ However, the reservation based on aesthetics runs counter to the arguments of writers on library handwriting. The so-called library hand was not an art form, but a highly disciplined system. Debates about the use of the joined or disjoined hand did not concern beauty, but speed and legibility. The differences between letters were to be accentuated, but uniformity in letter size, slant, blackness of line, and spacing was considered essential. The mixing of styles, shading, and fine strokes-characteristic of "beautiful" penmanship-was discouraged. Good library handwriting was to be, as one librarian stated in 1885 , "as near to type as possible." The disjoined hand, though 25 percent slower to produce, was preferred by library educators because it looked more like print. ${ }^{23}$

\section{The card catalog was one of those li- brary inventions that greatly helped individual libraries, but it did so at the expense of library cooperation.}

There was concern that the typewritten product would be prone to errors because "the cataloguer's mind would be concentrated as much on the manipulation of the keys as the contents of the book." Also, this big machine was thought to disturb the comfort of the cataloger. Catalogers were used to spreading books out on a desk in order to digest their contents, but the typewriter made this difficult:

The book must either be taken up in the hands or placed at the side of the machine and the body twisted in order to look at it. In the case of an ordinary octavo, this may not occasion much inconvenience, but the case is otherwise with stout quartos or folios. ${ }^{24}$

The worry about typewritten errors persisted. In 1914, William Warner 
Bishop, in his Practical Handbook of Modern Library Cataloging recommended that the typewriter be used for simple cataloging where speed is required, but for "recondite books," found in research libraries, where "judgment, accuracy, and selection are the important factors" (and where speed is of secondary importance), he recommended the "ancient practice of writing the original card by hand with the pen." 25

Another objection to the typewriter had to do with the quality and longevity of the product. How permanent were typed catalog cards? Would they fade with time? This concern was so great in 1900 that a librarian in Albany, New York, subjected typewritten cards to sunlight, rain, heat, and even boiling. The results proved that ink from the typewriter was quite sturdy and could be removed only with strong chemicals. ${ }^{26}$

A skilled operator could type much faster than he or she could write, but the advantage of the typewriter in producing cards was less clear cut. There were about a dozen typewriter brands employed in library work at the turn of the century, but some were clearly not manufactured with card typing in mind. Some machines could not adequately keep cards from shifting position when the platen revolved; others could not provide uniform spacing, were incapable of handling card stock, or would bend the card so badly that they were permanently misshapen. Finally, it was quite a few years before typewriters had all the keys desired by librarians for card production.

Clearly, some librarians disliked typewriters because they were machines, but others believed, as did Bishop, that there were some instances when the pen better suited the catalog card. Even in an ideal situation, the typing of cards required many steps: inserting the card into the machine, setting the margins, rolling the platen to the correct position on the card, and typing the text. For added entries where no more than one line (and in many cases just one word) was to be inserted on the top of the card, the typewriter was clearly inefficient and some libraries continued to handwrite this information on printed Library of Congress cards many years after they had integrated typewriters into normal operations.

\section{The library world constantly looked to machine and mind for improvement.}

Typewriters changed work procedures and the work force within libraries, though the transition was rarely noted in the library literature. The typewriter required skilled workers and, at least at the outset, libraries would have had fewer typists than those skilled in library hand. As one librarian stated in 1907, "If the typist is ill or absent, the catalogue must wait." ${ }^{27}$ We can imagine that the typewriter set up new ways of differentiating staff, with implications for wages and the potential for intergenerational friction, but the record is not rich in this area. Library educators, though, for years advised new library school students to learn to use the typewriter because it would enhance their chances of finding employment. ${ }^{28}$

Library hand continued to be supported by the profession. The New York State Library School published a library handwriting guide for its students as late as 1916, and even in 1930, cataloging textbooks urged library students to acquire proficiency in the art. ${ }^{29}$ Haverford College produced cards with pen and ink until 1915, and I can still remember the supply closet at the Dartmouth College Library in 1975, with its array of old fountain pens, ink holders, and supply of ancient nibs, all unused for years-a monument to a past age.

\section{CONCLUSION}

Today, we recognize that neither books nor libraries themselves are sacred, and the profession has progressed to a point where it counts on future technology to solve its problems. In the past, librarians were afraid that such a preoccupation would divorce them from the scholar and, indeed, in the case of the 
card catalog, the relationship with practicing scholars was a major issue for discussion.

It is often said that librarians hesitate to adopt new methods and procedures and will hold on to established work patterns far longer than is necessary. During the half century after the nation's centennial, we see the persistence of established methods, but this is not evidence of stagnation, for the library world constantly looked to machine and mind for improvement. Successful labor-saving devices not only filled a definite need and were affordable, they were also adaptable to the changing world of libraries. For inventions that could not be modified or that would require substantial capital outlays, the library field proved a difficult task master. Library handwriting methods, as primitive as we may regard them today, persisted well into the twentieth century because they could be adapted to a card-based cataloging environment. Some libraries simply could not afford typewriters, but there were also those that, on principal and from experience, believed that for certain operations, pen and ink were more efficient and would result in greater cataloging accuracy.

The replacement of one technology or method by another has never been a simple matter for libraries. The world in which inventions of the past were adopted and discarded depended on budgets, the requirements of the labor force, the reaction of library users, and also sentiment, the attitudes, feelings, and opinions of librarians and library managers.

\section{REFERENCES AND NOTES}

1. Richard Garnett, Essays in Librarianship and Bibliography (New York: Harper, 1899), p.253-57.

2. John Cotton Dana, "Anticipations, or What We May Expect in Libraries," in Libraries: Addresses and Essays (New York: H.W. Wilson, 1916), p.149-50.

3. "Fireproof Book," U.S. Patent no. 509,533, Official Gazette of the U.S. Patent Office 65:1293 (1893); Jim Ranz, "Alexander J. Rudolph and His 'New Method of Cataloging,'" Library Resources \& Technical Services 5:259-66 (Fall 1961); "Coin-Operated Holder for Books or Other Articles," U.S. Patent no. 426,098, Official Gazette of the U.S. Patent Office 51:515 (1890); "Coin-Actuated Book Receptacle," U.S. Patent no. 633,308, Official Gazette of the U.S. Patent Office 88:2144 (1899); "Coin-Controlled Book-Holder," U.S. Patent no. 644,776, Official Gazette of the U.S. Patent Office 90:1835-36 (1900).

4. "Improvement in Autographic Printing," U.S. Patent no. 180,857, Official Gazette of the U.S. Patent Office 10:227 (1876); H. J. Carr, "Duplicating Processes in Cataloguing," Library Journal 1:372 (June 30, 1877); Melvil Dewey, "Duplicating Processes," Library Journal 4:165 (May 1879). Edison's own successor to the electric pen, the mimeograph, used paraffin paper and no electricity to produce stencils. The mimeograph proved adaptable for use with typewriters.

5. Technology is often thought to include systems using machinery and automation. Here, I am taking the broader definition of technology as "a technical method of achieving a practical purpose," Webster's Third New International Dictionary of the English Language (Springfield, Mass.: Merriam, 1971), or as "a method or process for handling a specific technical problem," Webster's New World Dictionary of the American Language (Cleveland, Ohio: William Collins, 1980). In this sense, the card catalog and library hand can be considered technologies.

6. Jim Ranz, The Printed Book Catalogue in American Libraries, 1723-1900 (Chicago: American Library Assn., 1964).

7. Finding-List of the Lake Forest University Library, (Waukegan, Ill.: Gazette Book and Job Print, 1893); Library of the University of Wooster (Wooster, Ohio: 1892); A Catalogue of the Library of The Bowdoin College: To Which Is Added an Index of Subjects (Brunswick, Me.: The College, 1863). The St. Lawrence University catalog consisted of "five bound volumes covering the period 1856 to approximately 1880 , with handwritten entries for library acquisitions. There [was] one sequence for author entries and another for titles, 
with what appear[ed] to be an accession number in the margin" (information provided by Richard Kuhta, University Librarian). The Davidson College catalog used alcove and shelf locations instead of classification numbers (information provided by Leland Park, Director of the Library).

8. Catalogue of the Library of Haverford School (Philadelphia: W. Brown, 1836).

9. Roger Michener, The Bowdoin College Library: From Its Beginning to the Present Day (M.A. thesis, Univ. of Chicago, 1972), p.124.

10. Justin Winsor, "The Condition of Italian Libraries," Nation 53:27 (July 9, 1891).

11. "The Coming Catalog," Library Journal 23:670 (Dec. 1898).

12. Winsor, "Italian Libraries," p.27.

13. Ranz, "Alexander Rudolph," p.265.

14. See discussions in Library Journal 17:92 (Mar. 1892) and 18:425 (Oct. 1893).

15. John Cotton Dana, "Library Problems," in Libraries: Addresses and Essays, p.57.

16. Fremont Rider, "The Possibility of Discarding the Card Catalog," Library Quarterly 8:329 (July 1938).

17. Ibid., p.330.

18. Ibid.

19. Donald Hoke, Ingenious Yankees: The Rise of the American System of Manufactures in the Private Sector (New York: Columbia Univ. Pr., 1990), p.132-78.

20. In a 1902 survey, eighteen of sixty-six libraries selected at random did not use typewriters in cataloging work. See Caroline Wandell, "The Typewriter for Card Catalogs," Library Journal 27:268 (May 1902). No further survey evidence of when libraries adopted typewriters exists, but information gathered for individual libraries suggests wide differences in first typewriter use. For example, Haverford College began using typewriters to produce catalog cards in 1915; the College of Wooster Library purchased its first machine, a Remington Noiseless, in the early 1920s.

21. Bruce Bliven, The Wonderful Writing Machine (New York: Random, 1953), p.68-71.

22. "The Typewriter and Its Employment for Cataloguing," Library Association Record 3:118 (1901).

23. "Library Handwriting," Library Journal 10:321 (Sept./Oct. 1885). Manuals on library handwriting techniques were published as early as 1887, Library Notes 1:273-82 (Mar. 1887); the last was Library Handwriting: A Guide for the Use of Students in the New York State Library School (Albany: Univ. of the State of New York, 1916). For a view of library hand by a library educator, see Alice B. Kroeger, "Instruction in Cataloging in Library Schools," Library Journal 32:111 (Mar. 1907).

24. "The Typewriter and Its Employment for Cataloguing," p.118.

25. William Warner Bishop, Practical Handbook of Modern Library Cataloging (Baltimore: Williams and Wilkins, 1914), p.23-24.

26. Wandell, "The Typewriter for Card Catalogs," p.268.

27. "Handwriting for Manuscript Catalogues," Library World 10:86-87 (1907).

28. In 1923, the Williamson report criticized library schools for putting so much emphasis on skillful typewriter use by their students. He believed that this and the requirement by some schools that librarians in training also acquire facility in "vertical or library handwriting" discouraged "able and ambitious college men and women" from choosing librarianship as a career. See Charles C. Williamson, Training for Library Service: A Report Prepared for the Carnegie Corporation of New York (New York: Merrymount Press, 1923), p.32-33.

29. Margaret Mann, Introduction to Cataloguing and the Classification of Books (Chicago: American Library Assn., 1930), p.105. 